\title{
Relationships between garnet and clinopyroxene in Vitim mantle xenoliths: evidence of the polystage growth and melt percolation?
}

\author{
Ashchepkov I.V $V^{l}$, Salters V.J.R. ${ }^{2}$, Andre L. ${ }^{3}$ \\ 1. UIGGM SD RASc, Novosibirsk, Russia, pr. Ac. Koptuga 3 \\ 2. Dept of Geol, FSU, Talahassee, Florida, US \\ 3. Royal Museum of the Central Africa, Tervuren, Belgium
}

Mineral grains from Vitim garnet lherzolites were analyzed for the trace elements with the SIMS and ICP MS techniques. The variations of the trace element geochemistry reveal the heterogeneity of the mineral grains what is much more pronounced for the garnet then for the clinopyroxenes.

The REE patterns for the melts parent for the garnet and clinopyroxenes determined using the D mineral-melts are essentially different. These can't be produced by the discrepancy in the partition coefficients because the temperature for common garnet lherzolites vary within $1000-1100^{\circ} \mathrm{C}$ rarely rising up to $1200^{\circ} \mathrm{C}$. The $\mathrm{D} \mathrm{Ga}$ /melt used was calculated from the $\mathrm{D}_{\mathrm{Ga} / \mathrm{Cpx}}$ equilibrated garnet peridotite and $\mathrm{D}_{\mathrm{Cpx} / \text { melt }}$ (Hart, Dunn, 1993). Garnet parental melts often reveal Ce minimums fluctuated at the same sample and grain. They also reveal elevated La and Ce and convex downward L-MREE part. This features together with the similarities at HSFE with the experimentally obtained mantle garnets in lherzolites (Sweeney et al., 1995) may indicate the origin from carbonatite intergranular liquid capable for the growth of garnet in some rocks. The minor interstitial Ce- carbonate may be the reason of Ce anomalies. LREE - MREE depression may be modeled with the AFC process when Gar dominate at the melting material and Cpx is more abundant at the crystallizing assemblage. The elevated HREE part for garnet parent melt may indicate the dissolution of early formed garnets.

The melting degree for the melts producing garnet is slightly lower then that of the clinopyroxenes and the calculated melting ensemble is more enriched in clinopyroxene and garnet comparing with those estimated for the melt in equilibrium with the clinopyroxenes. The minerals are suggested to be formed from the thin films of the percolated low degree volatile enriched partial melt which may vary in their composition during time and the stages of the percolation. The degree of melting agree with the amount of the interstitial glasses. The calculated difference between the bulk rock and those determined from the minerals also satisfy the composition of the partial melt with the melting degree near $1-1.5 \%$ which is close to determined with the fraction melt equations.

Garnet and clinopyroxene in several types of lherzolites are at the different structural positions. For slightly higher in temperature lherzolite subgroup where the large garnet grains are surrounded with the olivine aggregate forming channels. At the other grains the rounded garnet - two-pyroxene clusters with the subordinated olivine are typical. They may be produced due to the decomposition of earlier (majorite?) garnet. At the third, relatively lower temperature group, garnet and clinopyroxenes form the equilibrated intergranular aggregate which is found as the microvein associations at the structure. In several lherzolites of such type the intergranular association is represented with the spinel clinopyroxene ensemble which form the lenses of percolation at the garnet lherzolite structure. And the last is the thin garnet rims around the large spinel grains which were formed as a result of cooling or more probably due to reaction with the moving phase.

The trace element compositions melt produced garnet and clinopyroxene at the equilibrated and equigranular structures with the signs of percolation reveal spoon like patterns suggesting chromotographic effect or AFC (Fig1.). Those with the larger porphyric garnets differ in composition of the parent melts for this two minerals that are suggested to be formed during the several stages of the percolation. Thus the disequilibrium between garnet 
and clinopyroxene is a common feature of the mantle lherzolite assemblages as was found from the isotopy (Gunther, Jagoutz, 1994)

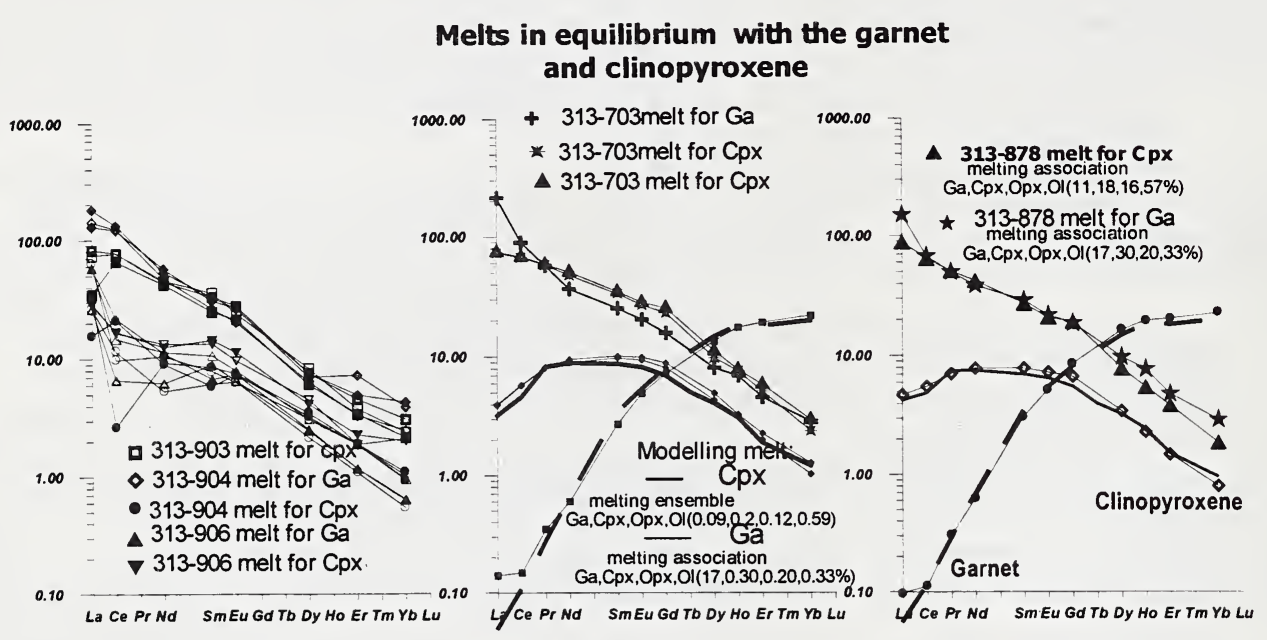

Fig.1. The REE patterns for the melts in equilibrium with the garnets and clinopyroxenes in

Vitim lherzolites. Analized mineral patterns and their modelled compositions.

\section{Refferences}

Hart, S.R. and Dunn, T., 1993. Experimental cpx/melt partitioning of 24 trace elements.

Contrib. Mineral. Petrol. 113, 1-8.

Sweeney, R.J., Prozesky, V. and Przybylowicz, W. 1995. Selected trace and minor element partitioning between peridotite minerals and carbonatite melts at $18-46 \mathrm{~kb}$ pressure Geochim.Cosmochim.Acta. 59:18, p. 3671-3683

Gunther M., Jagoutz E. 1994. Isotopic disequilibria ( $\mathrm{Sm} / \mathrm{Nd}, \mathrm{Rb} / \mathrm{Sr}$ ) between mineral phases of coarse grained, low temperature garnet peridotites from Kimberley Floors, southern Africa, In: H.A. Meyer \& O.H. Leonardos (Eds.), Proceedings of the Fifth International Kimberlite Conference. Araxa, Brazil (1991). 1; 354 -365. 